Article

\title{
A Conceptual Framework on Reconceptualizing Customer Share of Wallet (SOW): As a Perspective of Dynamic Process in the Hospitality Consumption Context
}

\author{
Jooa Baek ${ }^{1}(\mathbb{D})$ and Jaeseok Lee ${ }^{2, *(1)}$ \\ 1 Doctor of Business Administration Program, Goldey-Beacom College, Wilmington, DE 19808, USA; \\ baekj@gbc.edu \\ 2 Faculty of Hospitality and Tourism Management, Macau University of Science and Technology, Macao, China \\ * Correspondence: jaeseoklee@must.edu.mo
}

Citation: Baek, J.; Lee, J. A

Conceptual Framework on

Reconceptualizing Customer Share of

Wallet (SOW): As a Perspective of

Dynamic Process in the Hospitality

Consumption Context. Sustainability

2021, 13, 1423. https://doi.org/

$10.3390 /$ su13031423

Academic Editor: Sunghyup

Sean Hyun

Received: 31 December 2020

Accepted: 26 January 2021

Published: 29 January 2021

Publisher's Note: MDPI stays neutral with regard to jurisdictional claims in published maps and institutional affiliations.

\begin{abstract}
The consumer decision journey is a complex and situation-dependent process. In highly competitive markets with diverse brands in the hospitality industry, it is important to understand how customers' wallets are allocated to a particular brand among a set of competing brands. A review of the literature indicates that customers generally follow a previous purchasing experience and its evaluation (e.g., satisfaction, preference) but may change their former decisions at the purchasing moment through the dynamic process. This study builds upon the concept of brand categorization to understand complex choice behavior and the customer's share of wallet. This study proposes a conceptual framework incorporating several recent theoretical developments in consumer research to better understand customers' purchasing behavior in the hospitality industry. As such, it provides guidelines for designing a more effective marketing and communication strategy for hospitality entities.
\end{abstract}

Keywords: share of wallet (SOW); consumer choice behavior; brand categorization

\section{Introduction}

As market competition is getting fierce, consumers perceive brands within a product/service category increasingly similar to one another, and brand differentiation is weakened over time [1]. Like many other industries, competition in the hospitality industry arises from the existence of a large number of brands offering similar products [2]. In accordance with this competitive market, consumers are steadily segregating their purchases among multiple brands in most hospitality business categories (e.g., hotel, restaurant, and airline). Consequently, much literature has shown that customer loyalty is an essential goal of marketing efforts for most service companies to achieve a competitive advantage [3-5]. However, despite the emphasis on loyalty, brand loyalty has been weakening by degrees [6]. Consumers may not be loyal to a particular brand any longer and retain polygamous loyalty to several brands more and more [3,7,8]. Rust, Lemon and Zeithaml [7] suggested a "more realistic scenario" in which consumers repeatedly evaluated their experience with a brand and a product or service over a period of time with a number of potential brands in mind; namely, they leave and return to build a relationship once, while being non-loyal at times [9]. For this reason, how much a consumer spends on a specific brand, i.e., the share of purchases in the certain product category as opposed to its competitors, has been getting much attention to understand consumer choice behavior [10]. In recent hospitality literature, scholars have also suggested that consumer choice behavior is becoming dynamic [11,12]. Consumers' needs differ from both situation to situation and person to person, and they constantly reassess their decisions by giving the intention of purchase [8], obtaining extra or up-to-date information [13], and evaluating diverse criteria, e.g., price, product's performance, convenience, etc. [14]. 
The managerial relevance of positive relationships between satisfaction and wallet share has come into question in recent years due to the dynamic structure of brand choice behavior $[15,16]$. When consumers encounter a brand choice situation, competitive brands among numerous brands existing in the consumer's processed set may simultaneously affect the purchasing behavior $[17,18]$. Indeed, consumers' purchase intention toward a specific brand is determined by the attitude toward a focal brand and other competitive brands in the consideration set [19]. In a nutshell, the attitude toward the preferred brand alone does not inform a company about how customers change their consumption or spending patterns [10].

Despite its importance, there is a lack of research understanding the decision-making process of share of wallet and consideration set size in a consumer's wallet allocations. This research takes an initial step to examine the competition among brands and identify how competing brands are categorized. In this regard, this study aims to develop an advanced conceptual framework describing consumers' dynamic choice behavior affecting customer share of wallet (SOW) in response to the recent theoretical development in consumer behavior.

\section{Conceptualization of Dynamic Consumer Choice Behavior}

As evidenced in many disciplines, the marketing paradigm has shifted from a productcentric to a customer-centric culture: the latter focuses on building long-term relationships with the customer rather than transaction-based relationships [20]. To build strong relationships with existing customers, customer loyalty has to be a strategic objective of any business entity [21]. However, the undisputable conclusion has been drawn in extensive consumer research: consumers are less loyal to a single brand and more susceptible than they ever have been $[3,22,23]$. Even though brand loyalty has been considered the core element of relationship management strategies [24], it is declining more and more [6,22]. Indeed, as compared to the monogamous loyalty in the last decade, more customers hold polygamous loyalty more and more to several brands, dividing the category of purchases into multiple brands [21]. Thus, companies seek strategies to have more shares out of customers' wallets instead of aiming to have customers loyal only to their brand.

Furthermore, it is getting harder for service providers to satisfy customers, because they become more demanding and hold higher expectations [3,25]. Studies on consumer satisfaction have demonstrated that even satisfied consumers do not automatically buy the same brand over time $[25,26]$. Similarly, a nationwide indicator of customer satisfaction across the U.S. economy, i.e., the American Customer Satisfaction Index (ACSI), stated that higher brand-level satisfaction scores do not always convert to greater market shares, subsequently [27]. For example, results from the hotels set in 2014, Marriott marked the highest satisfaction score of 81 points and Hyatt, InterContinental, and Hilton scored 78 points for the second position. However, these results are not directly matched with their market share.

Given intense competition among brands and low brand differentiation, consumers have increasingly more choices. Customers are polygamous; they buy several brands, not just a single brand. Multi-loyalty and variety-seeking behavior was introduced in the middle of the last century. Brown [28] coined the term multi-brand loyalty in a study finding that 85 percent of families purchased more than one brand in many different product categories (e.g., convenience goods, shopping goods). Consumer behavior researchers suggested new terms to describe this phenomenon. "Choice repertoire" implies that a consumer can no longer be identified by a brand but rather by a set of brands ("consideration set", "evoked set", or "choice set") he or she will choose, with a specific probability, within the same product category. Consumers are more and more dividing their purchases among multiple brands in a category (i.e., share of wallet); it can explain the existence of "shared loyalties" or "divided loyalties", or even "multiple loyalties".

The idea of "customer share (of wallet)" allows companies to implement and design performance management strategies to achieve a greater share of customers' spending 
in a certain product category and thus boost profitability from not only existing but also potential customers $[10,16,29]$. A few previous studies considered that the customer share of wallet is an optimum measure of customers' behavioral loyalty in a more practical way [21]. That is, does how much money a customer spends on a specific brand represent that $\mathrm{s} /$ he behaviorally loyal to the brand per one particular period. However, this approach mainly focuses on cumulative understanding. All choice behaviors are taken together without considering individual characteristics (e.g., personality, previous experience, product knowledge) and situational factors (e.g., alternative attractiveness, switching cost, marketing effort).

Given the increasing trend of consumer share (of wallet) to several brands, consumers are likely to have a positive attitude toward multiple brands in most purchase situations, i.e., multi-loyalty. Service literature indicates that satisfied customers tend to be very loyal and repeatedly purchase a certain brand without hesitation in order to reduce unexpected risk and cost (e.g., mental processing and storage costs, fatigue, physical/mental search costs, and time) [30]. However, a high level of customer satisfaction does not always produce a high level of loyalty behavior [26,31-34]. Customers who classify themselves as "satisfied" switch brands even though those are their preferred brands [23,35]. More interestingly, customer satisfaction with frequently purchased brands alone does not reveal how customers change their spending patterns [10].

Moreover, the competitive market situation allows customers to easily switch among brands [36-38]. When consumers make a decision to visit a certain hotel or a restaurant, a fairly large number of brands exist in the customers' consideration set or brand choice repertoire. In this case, consumer's choice behavior may be induced by extrinsic (e.g., discount/promotional coupon, price reduction, membership points) and intrinsic (e.g., the need for social acceptance and belonging to a group, a desire to try a new product) factors [38]. Indeed, in the current competitive market environment (e.g., newly developed technology, information explosion, functional similarity between a brand), diverse alternatives and situational factors, such as e-commerce product pages [39], may affect every purchasing moment.

The hospitality literature indicated that customers often change their choice from one to another even though they have a favorable attitude toward a focal brand in order to optimize benefits [40]. Generally, consumers' perceptions and beliefs about a focal brand significantly affect consumers' choice behavior [41-44]. Then, the following questions arise: (1) how do consumers make their choice over a specific brand among the available ones in their consideration set with a favorable attitude? (2) How do multiple brands work with or compete with during the consumers' brand selection processes? [45-47]. To resolve this dilemma, researchers have suggested using a relative measure of satisfaction where satisfaction with the focal brand is expressed in a relative term compared to satisfaction with other competitors [48,49]. Purchase intention toward a particular brand has a positive relationship with a consumer's attitude toward the brand and negative association with one's attitudes toward other brands in the choice set in the buying situation [19]. Choice behavior is also affected by a set of alternatives under active deliberation until consumers make a final decision [18]. When consumers meet a brand choice situation among numerous brands, those competitive brands that existed in the consumer's processed set may affect the purchasing behavior [17]. Laroche and Brisoux [19] proposed and confirmed a multibrand model of intentions. This model proposes that a consumer's buying intention to a particular brand is affected by the allocation of attitudes toward all the alternative brands in the choice set. In other words, the attitude of the focal as well as other rival brands in the choice set simultaneously affects a purchase intention. Investigating the data on consumers' attitudes toward multiple beer brands in their choice set, researchers [19] tested both a direct effect and a competitive effect on purchase intention. The direct effect implies an attitude toward a particular brand is solely determined by a buyding intention toward the aforementioned brand exclusively, without considering attitudes toward other competing brands. Simultaneously, the competitive effect means that attitudes toward 
other competing brands may influence purchase intention toward the brand placed first. When consumers are faced with numerous brands, they tend to minimize a mental cost by simplifying their decisions, such as narrowing down to a smaller subset of these brands for their selection, which is called a consideration set [50-52]. However, those earlier models focused mainly on identifying whether or not the competitive effect of alternative brands exists between attitude and purchase intention rather than identifying the fundamental reasons and its process.

According to the definition of customer share of wallet, the process of dynamic choice behavior is perfectly fitted into these underlying mechanisms. Figure 1 describes the process of dynamic choice behavior with the brand categorization. It is suggested in this paper that the brand categorization process provides an excellent view to explain how consumers make a decision and/or respond in different purchasing situations. It is hoped that the framework presented in Figure 1 will be useful to broaden the vision of consumer purchasing behavior research in the hospitality context. It reflects hospitality service characteristics (i.e., perishability, heterogeneity, and intangibility) and includes the most salient elements such as how and what variables change the brand categorization process and choice behavior.

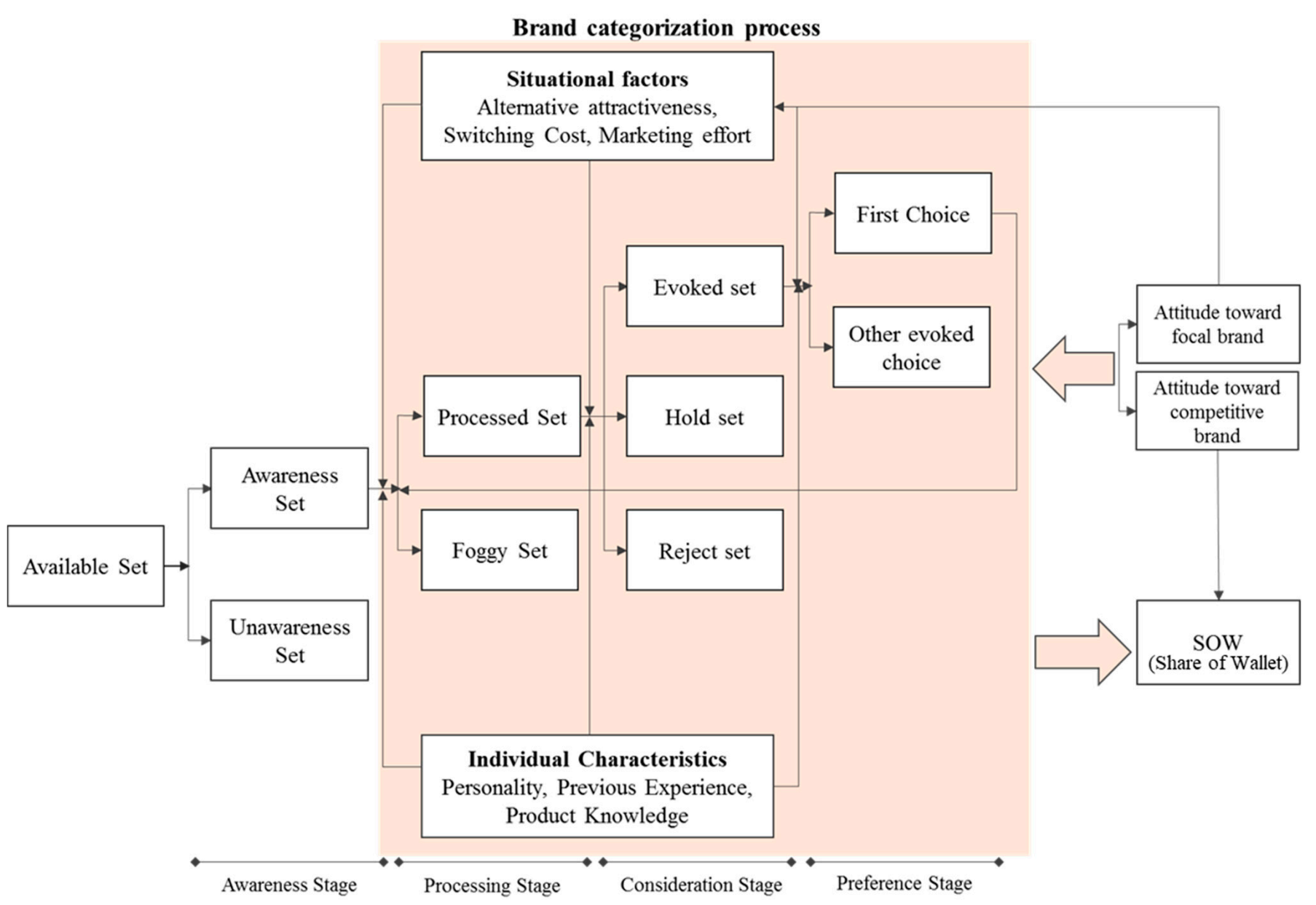

Figure 1. A proposed framework for consumers' dynamic choice behavior with brand categorization process.

\section{Dynamic Process of Brand Categorization}

\subsection{Brand Categorization}

Consumers hold favorable attitudes toward multiple brands in most purchase situations, although they ultimately have to limit their purchase to one or two at a time. With the rapid growth of the number of brands in the market and the standardization 
of functional attributes, understanding the formulation of consideration set and its effect on the consumer's choice behavior is important. Especially, entering into the consumers' consideration set has become a key strategic goal for companies [53]. Most previous studies of the consumer choice process describe it as a "sequence of stages" in which consumers can reduce the number of brands to a chosen brand throughout the multiple phases [54]. According to the Howard-Sheth model, when consumers are confronted with a wide range of alternatives, purchase decisions and preferences are impacted by multiple factors (i.e., social, psychological, and marketing factors) with a logical order of information processing $[17,55,56]$. Based on this concept, Brisoux and Laroche [57] expanded the model of consumers' awareness and brand categorization process. Consumers often use a two-stage process for the decision $[58,59]$ to lessen the complexity of the purchase decision. In the first step, consumers narrow down the overall set of alternatives (i.e., awareness set) to a smaller set (i.e., consideration set). Then, in the next step, a brand is selected for purchase from the consideration set in which the final decision is made [51,59]. The awareness set comprises the brands that are accessible from memory among all available brands in the marketplace. The decision process moved from the awareness set to the next set; the consideration set consists of the brands that are thoroughly reviewed and analyzed, moving from the awareness set [60]. Based on this model, available alternatives are first filtered out according to a simple non-compensatory rule, and the remaining options are reviewed more carefully using a compensatory rule to narrow it down [60]. Many researchers suggested that consumers tend to have four to seven brands in their final comparison because of minimizing the cognitive complexity of the choice situations and reducing their information load. However, this process is dynamic — brands may move from one set to another due to various factors including both internal and external ones. Internal factors include demographic, psychographic features and one's personal preferences. External factors consist of situations, e.g., marketing efforts, new product (and brand) introductions (or declines) and changes in competitive intensity and environment [19,57]. As shown in Figure 1, the brand categorization process can explain the fundamental reason consumers make (or change) their decision at the purchasing moment.

\subsection{Mechanism of the Brand Categorization Process}

\subsubsection{Awareness Set}

Consumers' awareness is divided into four different sets in general, such as evoked, foggy, hold, and reject [61]. According to Brisoux and Laroche [57] and Laroche and Brisoux [19], among available brands in the market (i.e., available set), consumers recognize several brands but do not recognize others. These are two main sets of brands, namely, the awareness set and unawareness set (refer to Figure 1). The unawareness set includes brands in which consumers are not fully aware and unconscious of their existence in the marketplace. The awareness set comprises brands of which consumers have a bit of awareness (whether they "come into mind" on a given occasion), and brands in this set are believed to be appropriate for the consumer's goal(s) or objectives. As its name implies, knowledge of the brands in this set is presumed to exist in individual memory and could be selected for processing. The awareness set is further broken down into a processed set and a foggy (i.e., unprocessed) set.

\subsubsection{Processed Set}

The processed set consists of three different sets, such as evoked, hold, and reject. Brands in this set tend not to be considered as alternatives for the final decision yet; in other words, consumers may have whether positive, negative, or even neutral attitudes toward them at this stage [19,57]. The first set, the evoked set, comprises brands that are thoroughly evaluated for all significant attributes and considered the most prominent in the repertoire for purchase decisions. The second hold set includes brands evaluated by consumers either not entirely or not appropriately at the consumption situation (e.g., too high in price to be placed in the consideration set or low enough not to be in the reject 
set). Those brands are not considered as alternatives but may have a possibility to move into the consideration set. The last category of brands in the processed set is the reject set. It is made up of brands that do not clearly meet consumer's minimum expectations and are rejected by consumers accordingly. Consumers would not consider these brands as alternatives for their purchase decision and carry unfavorable and negative attitudes on those brands.

\subsubsection{Consideration Set}

The consideration set is "a set of brands brought to one's mind on a particular choice situation or brands that consumers would consider buying in the near future" [54]. They are considered to be in the final purchasing decision, which is referred to as a choice set and evoked set; it is a central component of purchasing behavior models. As explained here, the consideration set through the brand categorization process may evolve until the consumer decides to make a final choice, and therefore, adding or deleting brands is necessary. Thus, one more brand can be added on each decision occasion, or even a large number of brands can be added if no active processing occurs prior to choice.

Taking these together (Figure 1), this study argues that consumers have a positive (or favorable) attitude toward several brands. Moreover, to make a decision, consumers would categorize the brand through each stage (i.e., whether situational and individual factors are worked or not); eventually, it will affect customers' share of wallet.

\section{Key Propositions}

Based on the literature reviewed, the following propositions are suggested to establish and conceptualize a framework that explains the consumer share of wallet as choice behavior and brand categorization process in the hospitality context.

Proposition 1. Customers' share (of wallet) allocations can be accumulated by each choice behavior.

Generally, share of wallet is measured as a customer allocation to a specific brand within a category over a certain period [25]. Originally, it has been defined "as the ratio of a customer's purchases in a particular category of products/services from a brand to the customer's total purchases of that category of products/services from all brands" [62,63]. Much research has demonstrated that there is a significant positive relationship between satisfaction and share of wallet $[29,48,64-67]$. Recently, however, the managerial relevance of such findings has raised questions, because the relationship tends to be positive but very weak $[15,16,68]$. One of the reasons for this result is postulated that only satisfaction level of the focal brand is considered when predicting share of wallet [16,69]. Further, as the number of competing brands providing a minimum level of satisfaction, other factors tend to play a greater role, and customers are more likely to compare the value of various alternatives [10]. It becomes harder to satisfy customers completely, because they become more demanding and hold higher expectations $[3,25]$. Customers frequently reevaluate their purchasing decisions using diverse criteria such that both affective (e.g., hedonic desire) and cognitive (e.g., product's price, performance, convenience) factors [4].

Proposition 2. Customers' attitudes toward a focal brand and competing brands significantly affect customers' share (of wallet).

Customer share is a relative term that expresses the portion of share to the selected brand compared with other competitors or alternative brands in the consideration set. Researchers in marketing and economics [18,70] argue that consumers' decisions rely on a relative attractiveness or position among choice sets, called the context effect (i.e., similarity, attraction, and compromise effects). Generally, consumers are more likely to keep highly preferred brands in the consideration sets than others. Further, if a brand is likely to be maintained in a customers' consideration set, the brand will be chosen for the final decision more often, and eventually for purchase by the customer. Following this, consumer's 
purchasing decision depends on other alternative attractiveness (i.e., competitive effect). Therefore, not only customers' favoritism toward a focal brand or its product/service but also those alternatives would be considered simultaneously as determinants of customer share (of wallet).

Proposition 3. Situational factors and individual factors play significant roles in determining the level and impact of brand categorization.

Many prior studies examined how individual and situational factors influence purchasing behaviors [71] and, more specifically, how such factors function in the brand categorization stage. This study argues that each individual is different in their choice behaviors as one considers the surrounded environment differently. These individual differences come from either inherent personal traits (e.g., impulsive tendency, flexibility) [71] or acquired individual factors (e.g., involvement, knowledge, experience, multibrand preference) [72-74]. Thus, customers recognize an opportunity in a new situation based on their individual factors, which in turn, both (situational and individual factors) influence the brand categorization process, allowing them either to keep the same brand of what they purchased (i.e., high share of wallet) or change others. For example, consumers will behave differently when they have additional choices (e.g., new brand, price discount) that they are not conscious or do not know previously. Additionally, it is well documented in hospitality literature that customers are greatly influenced by purchasing situations. This is because they carefully consider decision contexts (e.g., unavailability, information) during their decision-making (e.g., choosing alternative brands, unplanned impulsive purchasing/visiting) [75]. In hospitality, the brand categorization process, therefore, should be understood with a full understanding of the service context and characteristics (e.g., perishability, heterogeneity, and intangibility).

Proposition 4. Customers' choice behavior will be very dynamic and less stable through the brand categorization process.

This fourth proposition is formulated by putting the previous three propositions together. Based on the literature, individuals learn different ways of categorizing brands and change their purchase intention (i.e., brand categorization process). As mentioned above, the consideration set is dynamic both within and across usage occasions. Consumers process options in their memory, adding or deleting as necessary. Additional factors may be recalled or encountered during the brand categorization process. It probably implies that the ability to categorize brands that consumers are aware of can be learned through their prior experiences. For instance, if a person does lots of categorization successfully and is satisfied, his/her categorization may be much easier than before; then, his/her choice behavior will become more dynamic. Moreover, the customer's brand categorization process is influenced by a number of situations, and the process will be more dynamic as well. Thus, marketers should understand customer's choice behavior and its categorization process.

\section{Challenges for Future Research}

This study further suggests challenges and opportunities for future research within this framework. Consumers' decision making is a dynamic process [76,77]. However, hospitality literature on this topic is dominated by studies examining causal relationships among variables explaining consumer decision-making and choice. Such approaches cannot capture the actual process of consumer decision-making. Therefore, future research should be conducted by a process model in terms of an underlying generative mechanism (e.g., how does this happen or transfer over time?), paying more attention to an appropriate methodology in response to their research question. One of the possible solutions could be a quantitative modeling approach using simulation methods (e.g., agent-based model, 
fuzzy cognitive map), whereas others can study using qualitative methods (e.g., interview, case study).

Consumers' decision-making can be explained by various approaches used in other disciplines both conceptually and methodologically. For example, some researchers describe dynamic decision making as a sequential, constructive, and goal-striving task, which in turn, follows the prospect theory and motivation theory $[76,78]$. Finally, this study basically holds the concept on complex theory in mathematics and physics (e.g., chaos theory) that customer's decision making is a complex process over time and strongly influenced by surrounded situations either consciously or unconsciously [79]. In order to follow this notion, future research should consider collaborating with other disciplines or incorporating conceptual and methodological approaches to fully understand consumers' decision-making processes.

Especially, as noted above in the competitive market situation in the hospitality industry, the type of information and organization may suggest valuable insight to understand (e.g., why consumers change their decisions (i.e., brand choices)) why they were considered. Particularly, information layout/framing (e.g., how to visualize and display the information in the webpage, signage, advertisement, etc.) is one of the significant factors to explain a consumer choice behavior $[80,81]$. The hospitality literature indicates that customers' preferences often shift through the website design [82], and it can change purchasing behavior differently from their plan in order to optimize their benefits. This may bring out the need for understanding consumers' choice behavior in connection with the characteristics of online service setting (i.e., e-commerce). For example, the product information on the hotel website (e.g., the price information about a package product) may affect choice behavior. In this regard, future research should consider the nature of information and its impact on travelers' behavior in order to accurately understand travelers' decision making at the destination.

\section{Conclusions}

The goal of this study is to develop a better understanding of customers' share (of wallet) in the hospitality service industry where the brand categorization process enables them to change their wallet allocations. This study proposes a conceptual framework for a better understanding of consumers' decision-making process integrating the concept of dynamic choice behavior. In this study, several key characteristics and challenges for future research are suggested based on the previous literature in an effort to offer important implications for both academic researchers and marketing practitioners. Theoretically, this study provides the foundation for better understanding of the dynamic processes that mirror complex choice behavior at each consumption situations. This study would also help understand how consumers' impulsive purchasing behaviors formulate and what motivates consumers to behave differently. From a practical perspective, the results of this study will enable hospitality companies to better address the dynamic nature of consumers' brand choice behavior.

Author Contributions: Conceptualization, J.B.; investigation, J.B. and J.L.; resources, J.B.; writingoriginal draft preparation, J.B.; writing - review and editing, J.L.; visualization, J.B.; supervision, J.L.; project administration, J.L. All authors have read and agreed to the published version of the manuscript.

Funding: This research received no external funding.

Institutional Review Board Statement: Not applicable.

Informed Consent Statement: Not applicable.

Data Availability Statement: Not applicable.

Conflicts of Interest: The authors declare no conflict of interest. 


\section{References}

1. Li, Z. Future International Business Strategy of Chinese Automotive Manufacturers. Ann. Bus. Adm. Sci. 2010, 9, 13-22. [CrossRef]

2. Matovic, D. The Competitive Market Structure of the US Lodging Industry and Its Impact on the Financial Performance of Hotel Brands. Ph.D. Thesis, Virginia Tech, Blacksburg, VA, USA, 2002.

3. Bennett, R.; Rundel-Thiele, S. The brand loyalty life cycle: Implications for marketers. J. Brand Manag. 2005, 12, 250-263. [CrossRef]

4. Tanford, S.; Raab, C.; Kim, Y.-S. A Model of Hotel Defection at the Purchasing Stage. J. Hosp. Mark. Manag. 2013, $22,805-831$. [CrossRef]

5. Wang, C.; Wu, L. Customer loyalty and the role of relationship length. Manag. Serv. Qual. Int. J. 2012, 22, 58-74. [CrossRef]

6. Clancy, K.J. Save America's dying brands. Mark. Manag. 2001, 10, 36.

7. Rust, R.T.; Lemon, K.N.; Zeithaml, V.A. Return on Marketing: Using Customer Equity to Focus Marketing Strategy. J. Mark. 2004, 68, 109-127. [CrossRef]

8. Kim, W.; Ok, C.; Canter, D.D. Contingency variables for customer share of visits to full-service restaurant. Int. J. Hosp. Manag. 2010, 29, 136-147. [CrossRef]

9. Stern, P.; Hammond, K. The Relationship between Customer Loyalty and Purchase Incidence. Mark. Lett. 2004, 15, 5-19. [CrossRef]

10. Coyles, S.; Gokey, T.C. Customer retention is not enough: Defecting customers are far less of a problem than customers who change their buying patterns. New ways of understanding these changes can unlock the power of loyalty. McKinsey Q. 2002, 81-90.

11. Dioko, L.A.; So, S.-I.; Harrill, R. Hotel category switching behavior-Evidence of mobility, stasis or loyalty. Int. J. Hosp. Manag. 2013, 34, 234-244. [CrossRef]

12. Ha, J.; Jang, S. Variety seeking in restaurant choice and its drivers. Int. J. Hosp. Manag. 2013, 32, 155-168. [CrossRef]

13. Wirtz, J.; Brah, S.; Yanamandram, V.; White, L. Switching barriers in business-to-business services: A qualitative study. Int. J. Serv. Ind. Manag. 2006, 17, 158-192.

14. Simpson, B.J.; Radford, S.K. Situational variables and sustainability in multi-attribute decision-making. Eur. J. Mark. 2014, 48, 1046-1069. [CrossRef]

15. Hofmeyr, J.; Goodall, V.; Bongers, M.; Holtzman, P. A New Measure of Brand Attitudinal Equity Based on the Zipf Distribution. Int. J. Mark. Res. 2008, 50, 181-202. [CrossRef]

16. Mägi, A.W. Share of wallet in retailing: The effects of customer satisfaction, loyalty cards and shopper characteristics. J. Retail. 2003, 79, 97-106. [CrossRef]

17. Graves, B.B.; Howard, J.A. Marketing Management: Analysis and Planning. J. Mark. Res. 1964, 1, 87. [CrossRef]

18. Simonson, I.; Tversky, A. Choice in context: Tradeoff contrast and extremeness aversion. J. Mark. Res. 1992, 29, 281-295. [CrossRef]

19. Laroche, M.; Brisoux, J.E. Incorporating competition into consumer behavior models: The case of the attitude-intention relationship. J. Econ. Psychol. 1989, 10, 343-362. [CrossRef]

20. Reinartz, W.J.; Kumar, V. On the Profitability of Long-Life Customers in a Noncontractual Setting: An Empirical Investigation and Implications for Marketing. J. Mark. 2000, 64, 17-35. [CrossRef]

21. Cooil, B.; Keiningham, T.L.; Aksoy, L.; Hsu, M. A longitudinal analysis of customer satisfaction and share of wallet: Investigating the moderating effect of customer characteristics. J. Mark. 2007, 71, 67-83. [CrossRef]

22. Dekimpe, M.G.; Steenkamp, J.-B.E.; Mellens, M.; Abeele, P.V. Decline and variability in brand loyalty. Int. J. Res. Mark. 1997, 14, 405-420. [CrossRef]

23. Mittal, B.; Lassar, W.M. Why do customers switch? The dynamics of satisfaction versus loyalty. J. Serv. Mark. 1998, 12, 177-194. [CrossRef]

24. Jacoby, J.; Chestnut, R.W.; Fisher, W.A. A behavioral process approach to information acquisition in nondurable purchasing. J. Mark. Res. 1978, 15, 532-544. [CrossRef]

25. Jones, T.O.; Sasser, W.E. Why Satisfied Customers Defect. Harv. Bus. Rev. 1996, 12, 11. [CrossRef]

26. Skogland, I.; Siguaw, J.A. Are your satisfied customers loyal? Cornell Hotel Restaur. Adm. Q. 2004, 45, 221-234. [CrossRef]

27. Aksoy, L. How do you measure what you can't define? J. Serv. Manag. 2013, 24, 356-381. [CrossRef]

28. Brown, G.H. Brand Loyalty-fact of fiction. Trademark Rep. 1953, 43, 251.

29. Perkins-Munn, T.; Aksoy, L.; Keiningham, T.L.; Estrin, D. Actual Purchase as a Proxy for Share of Wallet. J. Serv. Res. 2005, 7, 245-256. [CrossRef]

30. Hauser, J.R.; Wernerfelt, B. An Evaluation Cost Model of Consideration Sets. J. Consum. Res. 1990, 16, 393-408. [CrossRef]

31. Carroll, B.A.; Ahuvia, A.C. Some antecedents and outcomes of brand love. Mark. Lett. 2006, 17, 79-89. [CrossRef]

32. Fournier, S. Consumers and Their Brands: Developing Relationship Theory in Consumer Research. J. Consum. Res. 1998, 24, 343-353. [CrossRef]

33. Mittal, V.; Kamakura, W.A. Satisfaction, Repurchase Intent, and Repurchase Behavior: Investigating the Moderating Effect of Customer Characteristics. J. Mark. Res. 2001, 38, 131-142. [CrossRef]

34. Yim, C.K.; Tse, D.K.; Chan, K.W. Strengthening Customer Loyalty through Intimacy and Passion: Roles of Customer-Firm Affection and Customer-Staff Relationships in Services. J. Mark. Res. 2008, 45, 741-756. [CrossRef]

35. Stauss, B.; Neuhaus, P. The qualitative satisfaction model. Int. J. Serv. Ind. Manag. 1997, 8, 236-249. [CrossRef] 
36. Colgate, M.; Lang, B. Switching barriers in consumer markets: An investigation of the financial services industry. J. Consum. Mark. 2001, 18, 332-347. [CrossRef]

37. Jones, M.A.; Reynolds, K.E.; Mothersbaugh, D.L.; Beatty, S.E. The Positive and Negative Effects of Switching Costs on Relational Outcomes. J. Serv. Res. 2007, 9, 335-355. [CrossRef]

38. Mazursky, D.; LaBarbera, P.; Aiello, A. When consumers switch brands. Psychol. Mark. 1987, 4, 17-30. [CrossRef]

39. Chu, H.-L.; Deng, Y.-S.; Chuang, M.-C. Investigating the Persuasiveness of E-Commerce Product Pages within a Rhetorical Perspective. Int. J. Bus. Manag. 2014, 9, 31. [CrossRef]

40. Beldona, S.; Racherla, P.; Das Mundhra, G. To Buy or Not to Buy: Indian Consumers' Choice of Online Versus Offline Channels for Air Travel Purchase. J. Hosp. Mark. Manag. 2011, 20, 831-854. [CrossRef]

41. Chen, M.-F.; Tung, P.-J. Developing an extended Theory of Planned Behavior model to predict consumers' intention to visit green hotels. Int. J. Hosp. Manag. 2014, 36, 221-230. [CrossRef]

42. Hwang, J.; Ok, C. The antecedents and consequence of consumer attitudes toward restaurant brands: A comparative study between casual and fine dining restaurants. Int. J. Hosp. Manag. 2013, 32, 121-131. [CrossRef]

43. Kim, E.; Ham, S.; Yang, I.-S.; Gil Choi, J. The roles of attitude, subjective norm, and perceived behavioral control in the formation of consumers' behavioral intentions to read menu labels in the restaurant industry. Int. J. Hosp. Manag. 2013, 35, 203-213. [CrossRef]

44. Susskind, A.M.; Brymer, R.A.; Kim, W.G.; Lee, H.Y.; Way, S.A. Attitudes and perceptions toward affirmative action programs: An application of institutional theory. Int. J. Hosp. Manag. 2014, 41, 38-48. [CrossRef]

45. Laroche, M.; Sadokierski, R. Role of confidence in a multi-brand model of intentions for a high-involvement service. J. Bus. Res. 1994, 29, 1-12. [CrossRef]

46. Tversky, A.; Kahneman, D. Rational Choice and the Framing of Decisions. In Multiple Criteria Decision Making and Risk Analysis Using Microcomputers; Springer: Berlin/Heidelberg, Germany, 1989.

47. Tversky, A. Intransitivity of preferences. Psychol. Rev. 1969, 76, 31. [CrossRef]

48. Bowman, D.; Narayandas, D. Linking Customer Management Effort to Customer Profitability in Business Markets. J. Mark. Res. 2004, 41, 433-447. [CrossRef]

49. Olsen, S.O. Comparative evaluation and the relationship between quality, satisfaction, and repurchase loyalty. J. Acad. Mark. Sci. 2002, 30, 240-249. [CrossRef]

50. Nedungadi, P. Recall and Consumer Consideration Sets: Influencing Choice without Altering Brand Evaluations. J. Consum. Res. 1990, 17, 263-276. [CrossRef]

51. Van Nierop, E.; Bronnenberg, B.; Paap, R.; Wedel, M.; Franses, P.H. Retrieving Unobserved Consideration Sets from Household Panel Data. J. Mark. Res. 2010, 47, 63-74. [CrossRef]

52. Terui, N.; Ban, M.; Allenby, G.M. The Effect of Media Advertising on Brand Consideration and Choice. SSRN Electron. J. 2009, 30, 74-91. [CrossRef]

53. Corstjens, J.; Corstjens, M. Store Wars: The Battle for Mindspace and Shelfspace; John Wiley \& Sons Ltd: Hoboken, NJ, USA, 1995; Volume 5.

54. Roberts, J.H.; Lattin, J.M. Development and testing of a model of consideration set composition. J. Mark. Res. 1991, 28, 429-440. [CrossRef]

55. Sheth, J.N.; Newman, B.I.; Gross, B.L. Why we buy what we buy: A theory of consumption values. J. Bus. Res. 1991, 22, 159-170. [CrossRef]

56. Bither, S.W.; Howard, J.A.; Sheth, J.N. The Theory of Buyer Behavior. J. Mark. 1971, 35, 102. [CrossRef]

57. Brisoux, J.E.; Laroche, M. A Proposed Consumer Strategy of Simplification for Categorizing Brands. In Evolving Marketing Thought for 1980; Summey, J.D., Taylor, R.D., Eds.; Southern Marketing Association: Carbondale, IL, USA, 1980; pp. 112-114.

58. Gensch, D.H. A Two-Stage Disaggregate Attribute Choice Model. Mark. Sci. 1987, 6, 223-239. [CrossRef]

59. Wright, P.; Barbour, F. Phased Decision Strategies: Sequels to an Initial Screening; Graduate School of Business, Stanford University: Stanford, CA, USA, 1977.

60. Kardes, F.R.; Kalyanaram, G.; Chandrashekaran, M.; Dornoff, R.J. Brand Retrieval, Consideration Set Composition, Consumer Choice, and the Pioneering Advantage. J. Consum. Res. 1993, 20, 62. [CrossRef]

61. Laroche, M.; Toffoli, R. Strategic brand evaluations among fast-food franchises: A test of two frameworks. J. Bus. Res. 1999, 45, 221-233. [CrossRef]

62. Peppers, D.; Rogers, M.; Dorf, B. Is your company ready for one-to-one marketing? Harv. Bus. Rev. 1999, 77, 151-160.

63. Verhoef, P.C. Understanding the Effect of Customer Relationship Management Efforts on Customer Retention and Customer Share Development. J. Mark. 2003, 67, 30-45. [CrossRef]

64. Baumann, C.; Burton, S.; Elliott, G. Determinants of customer loyalty and share of wallet in retail banking. J. Financ. Serv. Mark. 2005, 9, 231-248. [CrossRef]

65. Keiningham, T.L.; Cooil, B.; Aksoy, L.; Andreassen, T.W.; Weiner, J. The value of different customer satisfaction and loyalty metrics in predicting customer retention, recommendation, and share-of-wallet. Manag. Serv. Qual. Int. J. 2007, 17, 361-384. [CrossRef]

66. Keiningham, T.L.; Perkins-Munn, T.; Evans, H. The Impact of Customer Satisfaction on Share-of-Wallet in a Business-to-Business Environment. J. Serv. Res. 2003, 6, 37-50. [CrossRef] 
67. Keiningham, T.L.; Perkins-Munn, T.; Aksoy, L.; Estrin, D. Does customer satisfaction lead to profitability? The mediating role of share-of-wallet. Manag. Serv. Qual. 2005, 15, 172-181. [CrossRef]

68. Seiders, K.; Voss, G.B.; Grewal, D.; Godfrey, A.L. Do Satisfied Customers Buy More? Examining Moderating Influences in a Retailing Context. J. Mark. 2005, 69, 26-43. [CrossRef]

69. Keiningham, T.L.; Aksoy, L.; Buoye, A.; Cooil, B. FIRST Customer Loyalty Isn't Enough. Grow Your Share of Wallet. Harv. Bus. Rev. 2011, 89, 29-31.

70. Huber, J.; Payne, J.W.; Puto, C. Adding Asymmetrically Dominated Alternatives: Violations of Regularity and the Similarity Hypothesis. J. Consum. Res. 1982, 9, 90-98. [CrossRef]

71. Verplanken, B.; Herabadi, A. Individual differences in impulse buying tendency: Feeling and no thinking. Eur. J. Pers. 2001, 15, S71-S83. [CrossRef]

72. Burnham, T.A.; Frels, J.K.; Mahajan, V. Consumer Switching Costs: A Typology, Antecedents, and Consequences. J. Acad. Mark. Sci. 2003, 31, 109-126. [CrossRef]

73. Goode, M.M.; Harris, L.C. Online behavioural intentions: An empirical investigation of antecedents and moderators. Eur. J. Mark. 2007, 41, 512-536. [CrossRef]

74. Trijp, H.C.V.; Hoyer, W.D.; Inman, J.J. Why switch? Product category-level explanations for true variety-seeking behavior. J. Mark. Res. 1996, 33, 281-292.

75. Fuller, D.; Hanlan, J.; Wilde, S.J. The Identification and Implementation of Key Competitive Factors for Tourism Based Firms. Int. J. Hosp. Tour. Adm. 2007, 8, 73-90. [CrossRef]

76. Busemeyer, J.; Townsend, J.T. Decision field theory: A dynamic-cognitive approach to decision making in an uncertain environment. Psychol. Rev. 1993, 100, 432-459. [CrossRef] [PubMed]

77. Erdem, T.; Keane, M.P. Decision-Making Under Uncertainty: Capturing Dynamic Brand Choice Processes in Turbulent Consumer Goods Markets. Mark. Sci. 1996, 15, 1-20. [CrossRef]

78. Kahneman, D.; Tversky, A. Prospect Theory: An Analysis of Decision under Risk. Econometrica 1979, 47, 263-291. [CrossRef]

79. Simonson, I. Determinants of Customers' Responses to Customized Offers: Conceptual Framework and Research Propositions. SSRN Electron. J. 2003, 69, 32-45. [CrossRef]

80. Biehal, G.; Chakravarti, D. Information Accessibility as a Moderator of Consumer Choice. J. Consum. Res. 1983, 10, 1-14. [CrossRef]

81. Pan, B.; Zhang, L.; Law, R. The Complex Matter of Online Hotel Choice. Cornell Hosp. Q. 2013, 54, 74-83. [CrossRef]

82. Stringam, B.B.; Gerdes, J., Jr. An analysis of word-of-mouse ratings and guest comments of online hotel distribution sites. J. Hosp. Mark. Manag. 2010, 19, 773-796. [CrossRef] 